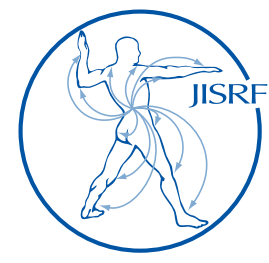

\title{
Trunnion Corrosion Causing Failure in Metal-on-Polyethylene Total Hip Arthroplasty with Monolithic Femoral Components
}

Manthe $M^{1}$, Blasser $K^{1}$, Beauchamp $C^{2}$, O'Connor M.I. ${ }^{3}$

\begin{abstract}
We describe nine patients who had total hip arthroplasty failure [titanium alloy monolithic stem, cobalt-chromium head (32 $\mathrm{mm}$ or $36 \mathrm{~mm}$ ), highly cross-linked polyethylene liner, metal socket] related to metal wear debris generated at the trunnion. Symptoms included pain with onset 2.9 years after THA. Preoperative serum cobalt metal ion levels were elevated [mean $8.8 \mathrm{ng} / \mathrm{ml}$ (normal $<0.9 \mathrm{ng} / \mathrm{ml}$ )] and were higher than chromium levels [mean $1.2 \mathrm{ng} / \mathrm{ml}$ (normal $<0.3 \mathrm{ng} / \mathrm{ml}$ )]. All patients had debridement of the periarticular soft tissues, stem retention, revision to ceramic head and new liner; two patients had acetabular revision. At early follow-up, 7 of 8 available patients did well, with improved cobalt ( $0.6 \mathrm{ng} /$ $\mathrm{ml}$ ) and little change in chromium levels. We recommend heightened awareness regarding this mode of failure.
\end{abstract}

Keywords: hip arthroplasty; corrosion;revision procedures

Level of Evidence: AAOS Therapeutic Level IV

\section{Introduction}

Corrosion at the head-neck taper may be emerging as an unusual and early mode of failure in conventional metal-on-polyethylene total hip arthroplasty (MoP THA; monolithic uncemented titanium alloy femoral component with narrower trunnion, modular cobalt alloy head, highly cross-linked polyethylene liner and uncemented acetabular component). The common use of different metals for the modular femoral head (cobalt-chromium alloy) and monolithic femoral stem (titanium alloy) in modern hip arthroplasty creates the potential for galvanic corrosion. Fretting and micromotion at the head neck junction
1 Megan Manthe, MD; Kurt Blasser, MD

Mayo Clinic, 4500 San Pablo Road South, Jacksonville, FL

2 Christopher Beauchamp, MD

Mayo Clinic, 13400 East Shea Boulevard, Scottsdale, AZ

3 Mary I O’Connor, MD

Yale School of Medicine, 800 Howard Avenue \#133, New Haven, CT 06519 (Direct reprint requests to Mary I O’Connor)

(C) 2016 Manthe, Blasser, Beauchamp, O’Connor. All rights reserved.

Authors retain copyright and grant the journal right of first publication with the work. Reconstructive Review follows the Creative Commons Attribution-NonCommercial CC BY-NC. This license allows anyone to download works, build upon the material, and share them with others for non-commercial purposes as long as they credit the senior author, Reconstructive Review, and the Joint Implant Surgery \& Research Foundation (JISRF). An example credit would be: "Courtesy of (senior author's name), Reconstructive Review, JISRF, Chagrin Falls, Ohio". 
can also result in the release of metal ions. Adaptation of narrower neck tapers to lower the risk of impingement may increase such micromotion. While failure of metal-on-metal THA due to metal wear debris has been well documented [1-3] and corrosion at the head-neck junction is known to contribute to the adverse local tissue reaction in these patients [4], failure of conventional MoP THA due to trunnion corrosion is now being reported [5]. The purpose of our study was to report our experience with early failure of conventional MoP THA related to corrosion at the modular headneck junction.

\section{Materials and Methods}

This is a retrospective case series of patients treated at two tertiary care, academic medical centers. Inclusion criteria were arbitrarily set to include patients who had undergone conventional primary total hip arthroplasty between January 2006 and December 2010. There were 2,703 primary arthroplasties performed at our two centers during this time frame. Revision procedures on these patients were performed between December 8, 2011 and May 13, 2013. Data was collected from review of the electronic medical record and radiographic images. Approval was obtained from the local Institutional Review Board.

Patients who presented with either clinical symptoms or radiographic abnormalities (or both) were identified for

Table 1: Patient Demographics

\begin{tabular}{|c|c|c|c|c|c|c|c|c|c|}
\hline Patient & $\begin{array}{l}\text { Age } \\
\text { (yrs) }\end{array}$ & Comorbidities & $\begin{array}{c}\text { Date of } \\
\text { Primary } \\
\text { THA }\end{array}$ & Sex & $\begin{array}{c}\text { Femoral } \\
\text { Component }\end{array}$ & $\begin{array}{l}\text { Acetabular } \\
\text { Size }(\mathbf{m m})\end{array}$ & $\begin{array}{l}\text { Stem } \\
\text { Size }\end{array}$ & $\begin{array}{l}\text { Head } \\
\text { Size/Neck } \\
\text { Length } \\
(\mathrm{mm})\end{array}$ & Taper \\
\hline 1 & 72 & $\begin{array}{c}\text { OSA, DMII } \\
\text { (metformin), } \\
\text { OA, Depression, } \\
\text { Nodular thyroid } \\
\text { disease }\end{array}$ & $11 / 3 / 2008$ & $\mathrm{~F}$ & $\begin{array}{c}\text { Stryker } \\
\text { Accolade }\end{array}$ & 50 & 3 & $32,-4$ & V40 \\
\hline 2 & 63 & $\begin{array}{l}\text { CAD, } \\
\text { HLD, HTN, } \\
\text { Hypothyroid, } \\
\text { Tinnitus }\end{array}$ & $10 / 27 / 2009$ & M & $\begin{array}{c}\text { Stryker } \\
\text { Accolade }\end{array}$ & 54 & 3 & $36,-5$ & V40 \\
\hline 3 & 63 & $\begin{array}{l}\text { HTN, HLD, } \\
\text { OSA, }\end{array}$ & $11 / 20 / 2006$ & M & $\begin{array}{c}\text { Zimmer M/L } \\
\text { taper }\end{array}$ & 56 & 11 & $32,-3.5$ & $12 / 14$ \\
\hline 4 & 68 & HTN, HLD, OA & $6 / 12 / 2007$ & $\mathrm{~F}$ & $\begin{array}{c}\text { Stryker } \\
\text { Accolade }\end{array}$ & 50 & 2 & $32,+0$ & V40 \\
\hline 5 & 53 & $\begin{array}{c}\text { Metastatic } \\
\text { seminoma, } \\
\text { CAD, Peripheral } \\
\text { neuropathy }\end{array}$ & $10 / 27 / 2007$ & M & $\begin{array}{l}\text { Stryker } \\
\text { Accolade }\end{array}$ & 52 & 3.5 & $32,+0$ & V40 \\
\hline 6 & 74 & $\begin{array}{l}\text { Hx Breast } \\
\text { Ca, HLD, } \\
\text { Hypothyroid, } \\
\text { Osteopenia }\end{array}$ & $5 / 30 / 2006$ & $\mathrm{~F}$ & $\begin{array}{c}\text { Stryker } \\
\text { Accolade }\end{array}$ & 54 & 4 & $36,+0$ & V40 \\
\hline 7 & 67 & $\mathrm{OA}, \mathrm{PAC}$ & $4 / 2 / 2007$ & $\mathrm{~F}$ & $\begin{array}{c}\text { Stryker } \\
\text { Accolade }\end{array}$ & 52 & 3 & $32,-4$ & V40 \\
\hline & $* * *$ & “ ، & $11 / 8 / 2010$ & $\mathrm{~F}$ & $\begin{array}{c}\text { Stryker } \\
\text { Accolade }\end{array}$ & 54 & 4 & $36,-4$ & V40 \\
\hline 8 & 59 & $\begin{array}{c}\text { DMII } \\
\text { (Metformin), } \\
\text { HTN, GERD, } \\
\text { Hypothyroidism, } \\
\text { Atrial } \\
\text { arrhythmia }\end{array}$ & $3 / 3 / 2006$ & $\mathrm{~F}$ & $\begin{array}{c}\text { Zimmer M/L } \\
\text { taper }\end{array}$ & 52 & 12 & $32,+0$ & $12 / 14$ \\
\hline 9 & 78 & HTN, Glaucoma & $5 / 12 / 2008$ & M & $\begin{array}{c}\text { Zimmer M/L } \\
\text { taper }\end{array}$ & 56 & 12.5 & $36,+3.5$ & $12 / 14$ \\
\hline
\end{tabular}

this study. The demographics of the study population are detailed in Table 1. Of the nine patients that comprised the cohort group, six had their primary arthroplasty at our institution. Eight of the nine patients presented for evaluation of pain (Figures 1 and 2). The final patient was asymp- 


\begin{tabular}{|c|c|c|c|c|c|c|c|c|c|}
\hline \multirow[b]{2}{*}{ Liner } & \multirow[b]{2}{*}{$\begin{array}{l}\text { Time to pain } \\
\text { (After index } \\
\text { op)(yr) }\end{array}$} & \multicolumn{4}{|c|}{ Pre-operative Serum Levels } & \multirow[b]{2}{*}{$\begin{array}{c}\text { Advanced } \\
\text { Imaging (CT/ } \\
\text { MRI) }\end{array}$} & \multirow[b]{2}{*}{ Aspiration } & \multirow[b]{2}{*}{$\begin{array}{c}\text { Time to } \\
\text { Revision } \\
\text { (after } \\
\text { index } \\
\text { THA) } \\
\text { (yr) }\end{array}$} & \multirow[b]{2}{*}{$\begin{array}{c}\text { Time to } \\
\text { Revision } \\
\text { (after } \\
\text { symptoms) } \\
\text { (yr) }\end{array}$} \\
\hline & & $\begin{array}{c}\mathrm{Cr}(\mathrm{ng} / \\
\mathrm{ml})(\mathrm{nml} \\
<0.3)\end{array}$ & $\begin{array}{l}\text { Co }(\mathrm{ng} / \\
\mathrm{ml})(\mathrm{nml} \\
<0.9)\end{array}$ & $\begin{array}{c}\text { ESR } \\
(\mathbf{n m l}<22 \mathrm{~mm} / \\
\mathbf{h r})\end{array}$ & $\begin{array}{c}\text { CRP } \\
(\mathrm{nml}< \\
8 \mathrm{mg} / \mathrm{L})\end{array}$ & & & & \\
\hline $10^{\circ}$ elevated & 2 & 0.5 & 15 & $*$ & $*$ & $\begin{array}{c}\text { Abnormal } \\
\text { enhancement } \\
\text { soft tissues, } \\
\text { Psoas } \\
\text { impingement }\end{array}$ & $\begin{array}{l}\text { Negative } \mathrm{Cx} \text {, turbid; } \\
\text { unable to perform } \\
\text { cell count (too } \\
\text { viscous) }\end{array}$ & 3.7 & 1.7 \\
\hline $10^{\circ}$ elevated & 2 & 0.2 & 2.1 & 8 & $*$ & $\begin{array}{l}\text { Abnormal } \\
\text { enhancement } \\
\text { soft tissues }\end{array}$ & $\begin{array}{l}\text { Negative } C x \text {, turbid; } \\
\text { cell count } 2,512\end{array}$ & 2.1 & 0.1 \\
\hline $20^{\circ}$ elevated & 3.4 & 1.3 & 9 & 40 & 76.3 & $\begin{array}{l}\text { Abnormal } \\
\text { enhancement } \\
\text { soft tissues }\end{array}$ & $\begin{array}{l}\text { Negative } C x, \text { turbid; } \\
\text { cell count } 7,000\end{array}$ & 5.4 & 2 \\
\hline $10^{\circ}$ elevated & 4.5 & 0.7 & 4.6 & 30 & 9.4 & $\begin{array}{l}\text { Lytic focus at } \\
\text { acetabulum }\end{array}$ & $\begin{array}{l}\text { Negative } C x \text {, turbid; } \\
\text { cell count } 1\end{array}$ & 4.7 & 0.2 \\
\hline $10^{\circ}$ elevated & No Pain & 0.2 & 11 & 33 & 7.1 & $\begin{array}{l}\text { Abnormal } \\
\text { enhancement } \\
\text { soft tissues }\end{array}$ & $\begin{array}{l}\text { Negative Cx; unable } \\
\text { to perform cell count } \\
\text { (limited fluid) }\end{array}$ & 5.3 & No Pain \\
\hline Neutral & 2 & 2 & 8.9 & 11 & 2.5 & $\begin{array}{l}\text { Abnormal } \\
\text { enhancement } \\
\text { soft tissues; } \\
\text { Pelvic } \\
\text { pseudotumor }\end{array}$ & $\begin{array}{l}\text { Negative } C x \text {, brown; } \\
\text { cell count } 20,966\end{array}$ & 6.3 & 4.3 \\
\hline $10^{\circ}$ elevated & 3.8 & 0.3 & 11 & 40 & 16.4 & $\begin{array}{l}\text { Abnormal } \\
\text { enhancement } \\
\text { soft tissues }\end{array}$ & $\begin{array}{l}\text { Negative } C x \text {, cloudy; } \\
\text { cell count } 1,001\end{array}$ & 5.7 & 1.9 \\
\hline $10^{\circ}$ elevated & 0 & 0.3 & 11 & 40 & 16.4 & $\begin{array}{l}\text { Abnormal } \\
\text { enhancement } \\
\text { soft tissues }\end{array}$ & $\begin{array}{l}\text { Negative } C x \text {, cloudy; } \\
\text { cell count } 1,001\end{array}$ & 2.5 & 2.5 \\
\hline$*$ & 0.1 & 3.1 & 1.2 & 17 & 9.6 & $\begin{array}{l}\text { Abnormal fluid } \\
\text { collection }\end{array}$ & $\begin{array}{l}\text { Negative } C x \text {; cell } \\
\text { count } 50\end{array}$ & 6.5 & 6.4 \\
\hline Neutral & 4.5 & 2.2 & 16 & $*$ & $*$ & $\begin{array}{c}\text { Abnormal fluid } \\
\text { collection with } \\
\text { metal debris } \\
\text { present }\end{array}$ & $\begin{array}{l}\text { Negative } \mathrm{Cx} \text {; } \\
\text { opaque; unable to } \\
\text { perform cell count }\end{array}$ & 4.9 & 0.4 \\
\hline
\end{tabular}

* Stryker components (Mahwah, New Jersey) consist of Trident hemispherical acetabular component with X3 polyethylene liner, Accolade TMZF stem manufactured from beta titanium alloy (TMZF) and cobalt-chromium alloy femoral head.

\# Zimmer components (Warsaw, Indiana) consist of Trilogy acetabular component with Longevity polyethylene liner, M/L taper femoral stem manufactured from titanium alloy (Ti-6Al-4V) and cobalt-chromium alloy femoral head. 
Figure 1: Patient \#7 was a 67-year-old female who had revision surgery 5.7 years following the index procedure.

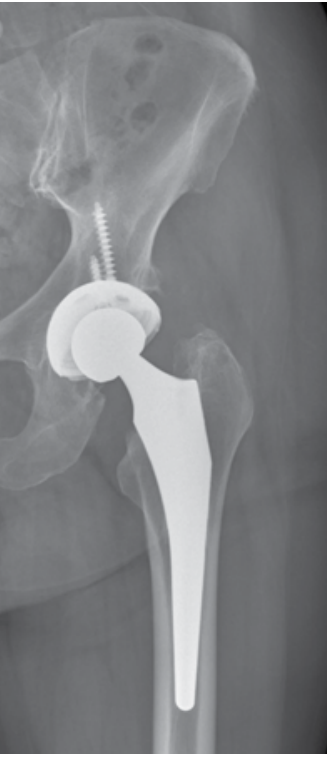

Figure 1a. Pre-revision Anteroposterior radiograph of the left hip showing mild osteolysis at the periphery of the acetabular component (zone 1) and a mild resorption of the medial femoral calcar (zone 7).

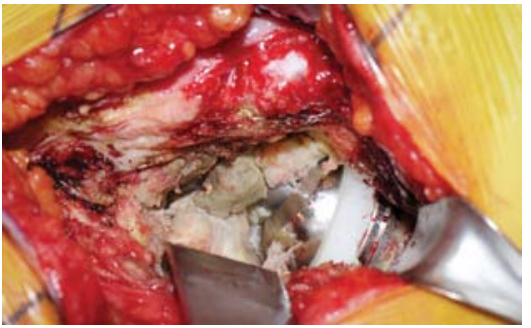

Figure 1b. Intraoperative photo showing necrotic debris and fibrosis within the hip joint. Notice that there is no visible abnormality at the junction of head and stem.

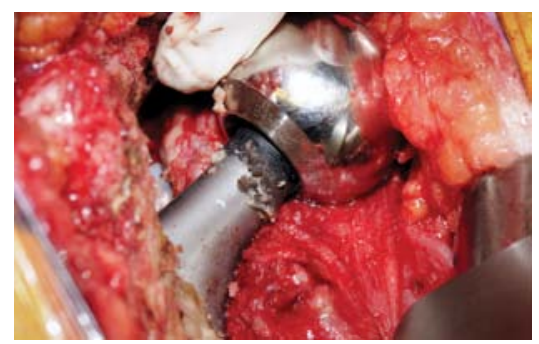

Figure 1c. With removal of head, extensive corrosive debris can be seen at trunnion/neck region.

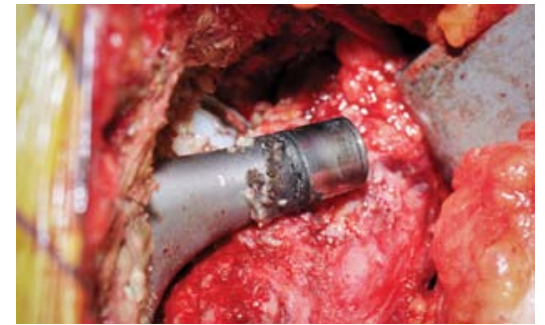

Figure 1d. Corrosive debris at base of trunnion; trunnion damage visible.

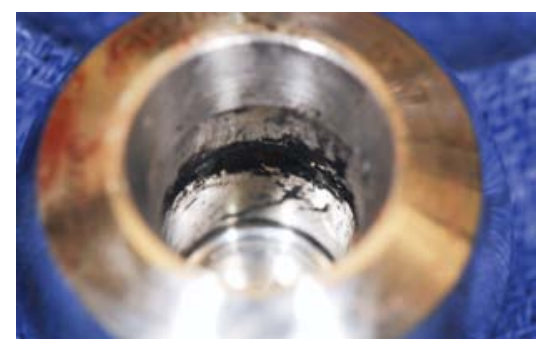

Figure 1e. Corrosion and debris within femoral head.

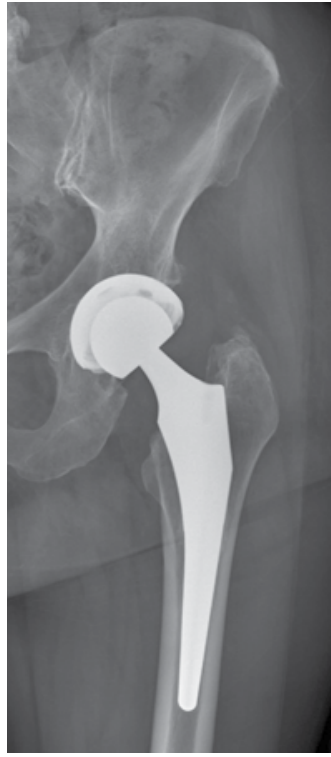

Figure lf.

Anteroposterior view of the left hip two months following revision polyethylene liner and conversion of the cobaltchromium to a ceramic femoral head.

Figure 2: Patient \#4 was a 68-year-old woman.

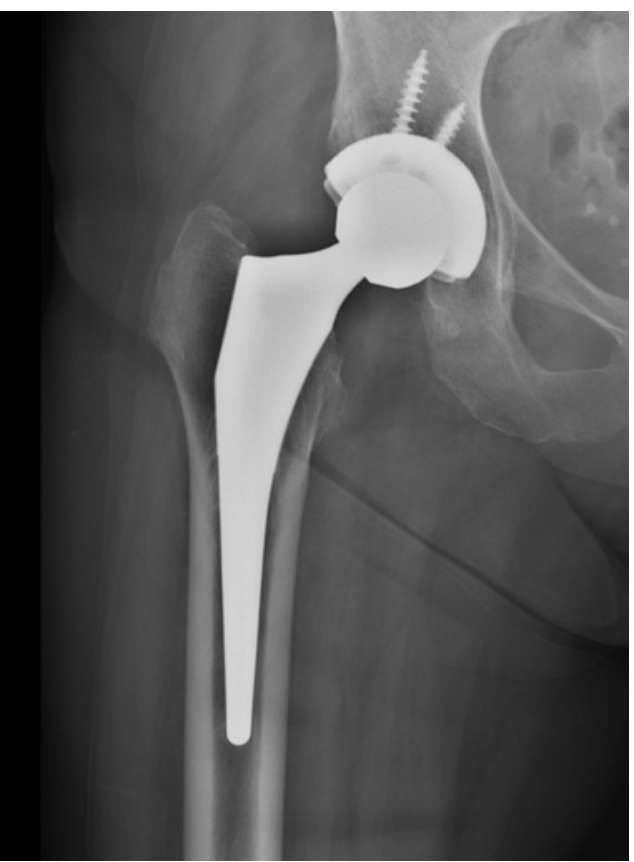

Figure 2a. Anteroposterior radiograph of the right THA three years following the index procedure. The patient is asymptomatic.

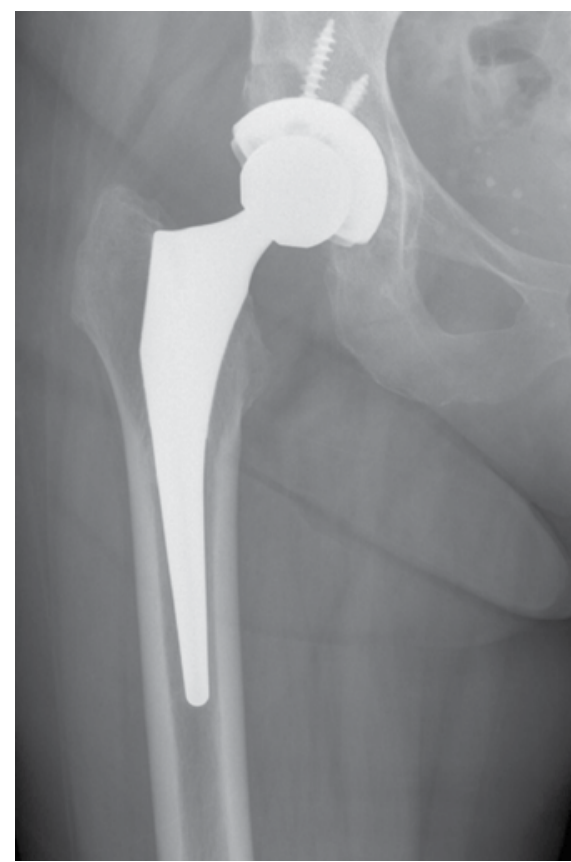

Figure 2b. Anteroposterior radiograph of the right THA 4.5 years following the index procedure showing interval development of acetabular bone loss in zone 1. Patient then developed hip pain.

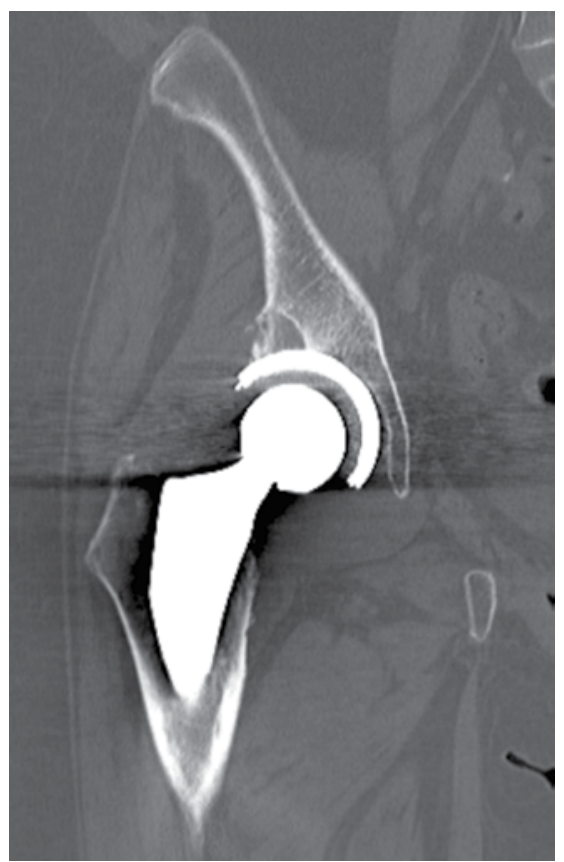

Figure 2c. Computed tomography scan of the right hip showing a fairly localized area of bone destruction with some surrounding sclerosis. Neoplasm (particularly metastatic disease) was included in the differential diagnosis. 
Figure 3: Patient \#5 was a 53-year-old male who underwent revision surgery 5.3 years after the index procedure.

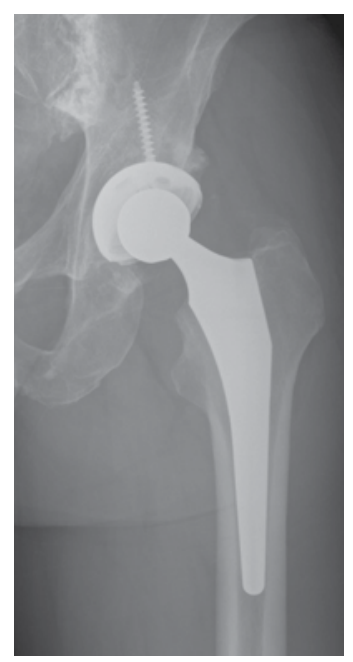

Figure $3 a$. Anteroposterior radiograph of the left hip three months after primary THA. Note the presence of the medial femoral calcar bone.

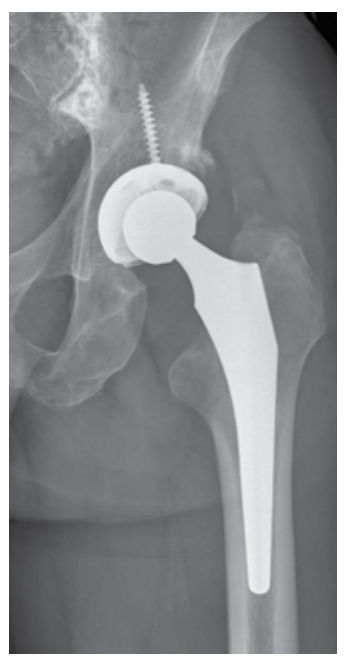

Figure $3 b$.

Anteroposterior

radiograph of the left hip prior to revision showing mild osteolysis at the periphery of acetabular component (zone 1) and a marked resorption of the medial femoral calcar (zone 7).

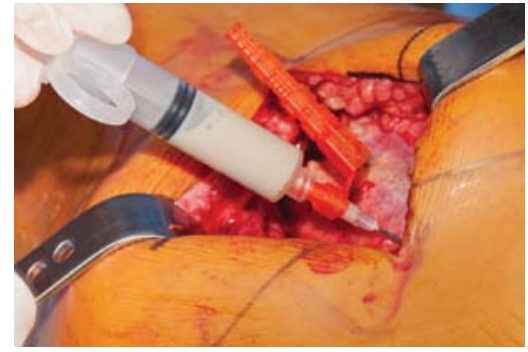

Figure 3c. Intraoperative aspiration of left hip joint showing grayish tinted white fluid.

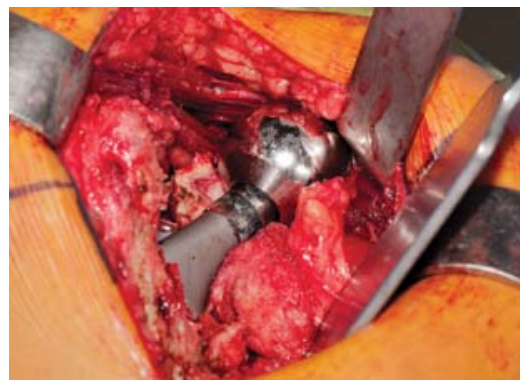

Figrue 3d. Intraoperative photograph of the femoral head being removed showing underlying debris due to trunnion corrosion.

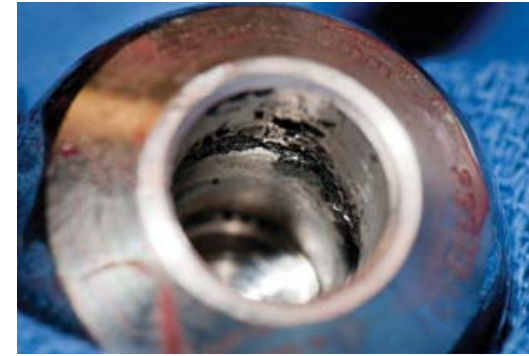

Figure 3e. Trunnion with debris and corrosion

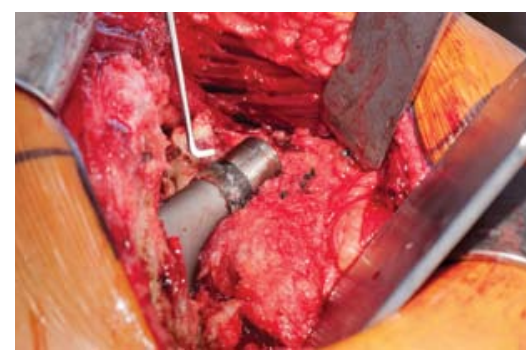

Figure 3f. Corrosion and debris within femoral head tomatic patient and had presented for routine follow-up and had an abnormality identified on radiographs (Figure 3). The variables studied included preoperative serum chromium and cobalt levels, preoperative hip-joint fluid analysis, and advanced imaging of the hip joint with computed tomography or magnetic resonance imaging with metal artifact reduction sequencing. As available, postoperative serum metal ion levels were documented as well as clinical status at most recent follow-up.

Ten revision procedures were performed in 9 patients; one patient underwent bilateral revisions (Table 2). In one patient, the preoperative diagnosis was psoas impingement, and serum metal ion levels were drawn immediately following revision after noting intraoperative findings consistent with metal debris generated at the trunnion. In the remaining patients, failure related to trunnion corrosion was suspected prior to revision. The average time between conventional THA and revision surgery was 4.7 years (range 2.1-6.5 years).

The surgical hip approach during revision surgery was dictated by surgeon preference and included 8 posterior approaches and 2 anterior approaches. All femoral stems were determined to be well-fixed and retained. Black flaky material at the head-neck junction was identified in all patients and was easily removed with either a damp lap pad, fresh blade, or bovie scratch pad. A titanium-alloy adapter sleeve was used in seven of ten constructs prior to ceramic head impaction on the taper. In the three cases where an adapter sleeve was not used, we employed an off label application based on the decision of the treating surgeon that the integrity of the trunnion was satisfactory. One wellfixed acetabular shell was revised in the patient who had the preoperative diagnosis of psoas impingement, and another acetabular shell was revised due to lack of ingrowth. All acetabular liners were revised with highly cross-linked polyethylene liners. All cobalt-chrome femoral heads were revised to ceramic heads.

\section{Results}

Clinical Presentation: In our small cohort, eight patients presented with or reported symptoms of groin, buttock, or thigh pain at an average of 2.9 years after initial THA (range 0.1-4.5 years). One asymptomatic patient returned for routine surveillance 1.9 years following his index procedure and radiographs revealed abnormal bone resorption (Patient 5). The average time between symptom presentation and revision surgery was 2.4 years (range $0.2-$ 6.4 years), and the time between index arthroplasty and revision surgery was 4.7 years (range 2.1-6.5 years). Of the index arthroplasties, 7 were composed of Stryker compo- 
Table 2: Revision Procedures and Findings

\begin{tabular}{|c|c|c|c|c|c|c|c|c|}
\hline Patient & Revision Procedure & $\begin{array}{l}\text { Head } \\
\text { size }\end{array}$ & $\begin{array}{l}\text { Head } \\
\text { Type }\end{array}$ & Liner & Shell & Stem & $\begin{array}{c}\text { Titanium } \\
\text { adapter sleeve }\end{array}$ & Intraop histology description \\
\hline 1 & $\begin{array}{l}\text { Shell, liner, head } \\
\text { exchange }\end{array}$ & $36,+5$ & Ceramic & Neutral & $\begin{array}{c}\text { Stryker } \\
\text { Trident } \\
\text { Hemispherical }\end{array}$ & Retained & No & NA \\
\hline 2 & $\begin{array}{l}\text { Liner }+ \text { head } \\
\text { exchange }\end{array}$ & $36,+0$ & Ceramic & Elevated rim & Retained & Retained & Yes & $\begin{array}{l}\text { "Fibrosis with focal } \\
\text { perivascular lymphocytic } \\
\text { inflammation; compatible with } \\
\text { ALVAL" }\end{array}$ \\
\hline 3 & $\begin{array}{l}\text { Liner }+ \text { head } \\
\text { exchange }\end{array}$ & $32,+0$ & Ceramic & Elevated rim & Retained & Retained & Yes & $\begin{array}{l}\text { "Degenerative synovial tissue; } \\
\text { bone with extensive necrosis" }\end{array}$ \\
\hline 4 & $\begin{array}{l}\text { Shell, liner, head } \\
\text { exchange }\end{array}$ & $36,+0$ & Ceramic & Elevated rim & $\begin{array}{l}\text { Zimmer } \\
\text { Continuum } \\
\text { Trabecular } \\
\text { metal }\end{array}$ & Retained & Yes & $\begin{array}{l}\text { "Necrotic debris with fibrous } \\
\text { soft tissue" }\end{array}$ \\
\hline 5 & $\begin{array}{l}\text { Liner + head } \\
\text { exchange }\end{array}$ & $36,+0$ & Ceramic & Elevated rim & Retained & Retained & Yes & $\begin{array}{l}\text { "Necrotic tissue \& patchy } \\
\text { chronic inflammation" }\end{array}$ \\
\hline 6 & $\begin{array}{l}\text { Liner }+ \text { head } \\
\text { exchange }\end{array}$ & $36,+0$ & Ceramic & Elevated rim & Retained & Retained & No & $\begin{array}{l}\text { "Infarcted tissue \& } \\
\text { hyalinization" }\end{array}$ \\
\hline 7 & $\begin{array}{l}\text { Liner }+ \text { head } \\
\text { exchange }\end{array}$ & $36,+0$ & Ceramic & Elevated rim & Retained & Retained & Yes & $\begin{array}{l}\text { "Patchy chronic inflammation } \\
\text { \& lymphoid aggregates" }\end{array}$ \\
\hline & $\begin{array}{l}\text { Liner + head } \\
\text { exchange }\end{array}$ & $\begin{array}{l}36 \\
-2.5\end{array}$ & Ceramic & Elevated rim & Retained & Retained & Yes & "Fibrinous degeneration" \\
\hline 8 & $\begin{array}{l}\text { Liner }+ \text { head } \\
\text { exchange }\end{array}$ & $\begin{array}{c}36 \\
+3.5\end{array}$ & Ceramic & Neutral & Retained & Retained & Yes & NA \\
\hline 9 & $\begin{array}{l}\text { Liner }+ \text { head } \\
\text { exchange }\end{array}$ & $32,-3$ & Ceramic & $\begin{array}{c}\text { Neutral, } \\
\text { Constrained }\end{array}$ & Retained & Retained & No & $\begin{array}{l}\text { "Fibrinous degeneration } \\
\text { present" }\end{array}$ \\
\hline
\end{tabular}

nents: Accolade TMZF stem with a V40 taper, a cobaltchromium alloy femoral head, and a Trident hemispherical acetabular component with an X3 polyethelene liner (Mahwah, New Jersey); 3 index arthroplasties were composed of Zimmer components: M/L taper femoral stem (Ti-6Al-4V) with a 12/14 taper, a cobalt-chromium alloy femoral head, and a Trilogy acetabular component with a Longevity polyethylene liner (Warsaw, Indiana).

Radiographic Findings: All patients had pre-revision radiographs. Two patients had bone resorption at the medial calcar, and one had an area of well-defined acetabular osteolysis. All patients had radiographs interpreted as hav- ing well fixed components. Seven of nine patients had metal artifact reduction sequencing magnetic resonance imaging (MARS MRI), which showed abnormal enhancement around the hip capsule and/or iliacus muscle; two patients also had large pseudotumors. The remaining two patients had computed tomography (CT) imaging of the hip, one detailing the osteolytic acetabular lesion and the other suggesting debris (Table 1).

Laboratory testing: Laboratory test results are detailed in Table 1. In all patients, the cultures from fluid aspirated from the hip joint were negative. Serum metal ion levels were evaluated on all patients and demonstrated elevated 


\begin{tabular}{|c|c|c|c|c|c|c|}
\hline \multicolumn{3}{|c|}{ Post-Operative Serum Metal Ion Levels } & \multirow[b]{2}{*}{ Complications } & \multirow[b]{2}{*}{ NOTES } & \multirow[b]{2}{*}{$\begin{array}{l}\text { Time to Latest } \\
\text { Clinical } \\
\text { Follow-up } \\
\text { after Revision } \\
\text { (mos) }\end{array}$} & \multirow[b]{2}{*}{$\begin{array}{l}\text { Patient comments at } \\
\text { clinic follow-up }\end{array}$} \\
\hline$\underset{<0.3)}{\operatorname{Cr}(\mathrm{ng} / \mathrm{ml})}(\mathrm{nml}$ & $\begin{array}{l}\text { Co }(\mathrm{ng} / \mathrm{ml}) \\
(\mathrm{nml}<0.9)\end{array}$ & $\begin{array}{l}\text { Time of blood draw } \\
\text { (post- revision) (mos) }\end{array}$ & & & & \\
\hline 0.6 & 2.1 & 3.7 & none & $\begin{array}{l}\text { Revised shell due to } \\
\text { intraop appearance of } \\
\text { retroversion }\end{array}$ & 5.7 & $\begin{array}{l}\text { "Doing better"; "Hip } \\
\text { feels less prominent" }\end{array}$ \\
\hline$*$ & 0.2 & 8.9 & none & $*$ & 8.9 & "Hip definitely better" \\
\hline 2.1 & 1.3 & 3.8 & $\begin{array}{c}\text { Died from } \\
\text { unrelated MI } 5 \\
\text { mos after revision }\end{array}$ & $*$ & 3.8 & $\begin{array}{l}\text { "Recovery better after } \\
\text { this than prior surgeries" } \\
\text { (prior to unrelated MI) }\end{array}$ \\
\hline 0.7 & 0.9 & 3.4 & none & $\begin{array}{l}\text { Revised shell because } \\
\text { acetabular component } \\
\text { found to not be ingrown }\end{array}$ & 7.7 & $\begin{array}{l}\text { "No problems while } \\
\text { walking" }\end{array}$ \\
\hline 0.2 & 1.8 & 3.2 & none & $*$ & 3.2 & $\begin{array}{l}\text { "Not much pain, patient } \\
\text { already returned to gym" }\end{array}$ \\
\hline 1.1 & 2.7 & 1 & $\begin{array}{l}\text { Infection, failed } \\
\text { Prostalac, now } \\
\text { with girdlestone }\end{array}$ & $*$ & 6.6 & $\begin{array}{l}\text { "Minimal discomfort, } \\
\text { less swelling; awaiting } \\
\text { ESR/CRP to normalize } \\
\text { prior to reimplantation" }\end{array}$ \\
\hline 0.4 & 7.6 & 1.8 & none & $\begin{array}{l}\text { Patient had bilateral } \\
\text { primary THA with } \\
\text { corrosion. Both hips } \\
\text { were revised as } \\
\text { described, with 5.1mos } \\
\text { between revisions. }\end{array}$ & 0.7 & $\begin{array}{l}\text { "Able to ambulate } \\
\text { independently" }\end{array}$ \\
\hline 0.3 & 1 & 4.7 & none & “ “ & 4.7 & $\begin{array}{l}\text { "Walking } 2 \text { miles a day } \\
\text { now, prior to revisions } \\
\text { couldn't walk } 2 \text { blocks" }\end{array}$ \\
\hline$*$ & $*$ & $*$ & none & $*$ & 1.9 & $\begin{array}{l}\text { "Really well with respect } \\
\text { to hip" }\end{array}$ \\
\hline$*$ & $*$ & $*$ & none & Large pseudotumor & $* * *$ & $* * *$ \\
\hline
\end{tabular}

cobalt levels, with a mean of $8.8 \mathrm{ng} / \mathrm{ml}$ (range $1.2-16 \mathrm{ng} /$ $\mathrm{ml}$; normal $<0.9 \mathrm{ng} / \mathrm{ml}$ ) and elevated chromium level of a mean of $1.2 \mathrm{ng} / \mathrm{ml}$ (range $0.2-3.1 \mathrm{ng} / \mathrm{ml}$; normal $<0.3 \mathrm{ng} /$ $\mathrm{ml})$.

Intraoperative Findings: At the time of revision, each modular head appeared fully engaged on the taper, based on intraoperative manual testing. Black debris at the headneck junction was identified in all patients. Our retrospective review of the operative reports did not detail if visible damage to acetabular liner was observed. Material analysis of the removed components was not performed. The structural integrity of each trunnion was inspected and found to be maintained. Synovial tissue hypertrophy and necrotic periarticular debris were seen in all patients, and a pseudotumor was identified in two patients. These abnormal tissues were debrided, as possible. Operative histology in seven cases showed fibrinous degeneration, chronic inflammation, and necrotic tissue, but no acute inflammation. Descriptions of intraoperative histology as dictated by pathology are shown in Table 2 . A variable degree of abductor muscle necrosis was also seen. We could not correlate the severity of tissue damage and preoperative metal ion level or time delay to revision procedure in this small series. Intraoperative cultures were negative in all patients. 
Descriptions of intraoperative histology as dictated by pathology are shown in Table 2.

Early clinical follow-up: Early results following revision surgery have been favorable in seven of eight patients with clinical follow-up. One patient has been lost to follow-up. These seven patients report significant improvement in hip pain and function (Table 2). In seven patients with postoperative metal ion levels, serum cobalt ion levels decreased from a preoperative mean of $8.8 \mathrm{ng} / \mathrm{ml}$ to 0.6 $\mathrm{ng} / \mathrm{ml}$ (range 0.2-1.3) at a mean time of 11 months after revision. There was little change in chromium levels from a preoperative mean of $1.2 \mathrm{ng} / \mathrm{ml}$ to a postoperative mean of $0.6 \mathrm{ng} / \mathrm{ml}$ (range 0.1-2.1 ng/ml).

Complications: One patient died months following revision surgery from an unassociated myocardial infarction. He reported clear improvement in hip pain at 4 month follow-up (Patient 3). Another patient with a large pseudotumor developed an acute postoperative infection and currently has a girdlestone (Patient 6). No postoperative dislocations have been reported.

\section{Discussion}

Corrosion at the tapered head-neck junction of a monolithic titanium alloy femoral component and modular cobalt-chromium femoral head can result in elevated serum metal ion levels and adverse local tissue reaction, leading to failure of the MoP THA (Table 3). Although an uncommon finding, trunnion corrosion can result in significant pain and debilitation for patients. Most recently, Cooper et al. reported on a cohort of 10 patients with failed MoP THA due to trunnion corrosion [5]. Although case reports have documented MoP trunnion corrosion and pseudotumor development throughout recent years [14,21-22,2527], our report of nine patients is the second series, to our knowledge, of early failure in MoP THA due to corrosion at the head-neck junction.

In our series, nearly all patients had pain that prompted advanced imaging and subsequent metal ion level testing. All patients had abnormal MRI or CT findings and elevated metal ion levels. In eight of nine patients, serum cobalt levels were dramatically elevated compared to serum chromium levels; a finding that was also reported by Cooper et al [5]. While Cooper et al. [5] did not report changes on radiographs of bone resorption, we identified osteolytic lesions in two of our patients. While we cannot conclude that there is a consistent clinical presentation for patients with failure of MoP THA due to trunnion corrosion, our experience suggests that metallosis due to trunnion corrosion should be considered in patients with pain within the first few years after MoP THA.

Revision of patients in our series to a ceramic-on-polyethylene bearing THA resulted in clinical improvement in all patients except one who developed a postoperative infection. Postoperative cobalt metal ion levels returned to normal levels at an average of 11 months from revision. Cooper et al. also reported reduction in postoperative serum metal cobalt levels in 6 of their patients in whom testing was performed [5]. While patients will require longer follow-up to assure clinical success, our early experience suggests that revision to a ceramicon-polyethylene bearing surface will effectively treat the metallosis associated with trunnion corrosion in these patients.

The etiology of trunnion corrosion at the head-neck junction in the patients in our series remains unclear. Implant design features, size selection of the femoral head component, surgical technique, and even patient factors may play a role in the development of trunnion corrosion. Reports from the field of implant dentistry have shown that titanium implant failure via corrosion is more likely to occur under conditions of increased serum glucose as well as increased acidity, as seen in conditions of inflammation and infection [6-8]. While our cohort had two patients with diabetes mellitus, our numbers are too small to comment on the role of elevated blood glucose and inflammatory conditions on the development of trunnion corrosion. Future research reviewing a larger cohort of patients could potentially identify patient comorbidities, which may increase the risk of subsequent trunnion corrosion in THA.
Table 3: Trunnion Corrosion with Monol

\begin{tabular}{|c|c|}
\hline Previous Study & $\begin{array}{l}\text { Patient } \\
\text { demographics }\end{array}$ \\
\hline $\begin{array}{l}\text { Walsh et.al. [21] } \\
2011\end{array}$ & $\begin{array}{l}\text { 79-year-old } \\
\text { male }\end{array}$ \\
\hline $\begin{array}{l}\text { Lindgren et. al. } \\
\text { [22] } 2011\end{array}$ & $\begin{array}{l}70 \text {-year-old } \\
\text { male }\end{array}$ \\
\hline $\begin{array}{l}\text { Bonnaig et. } \\
\text { al. [23] } 2011 \\
\text { (Titanium } \\
\text { morse taper } \\
\text { with Ceramic- } \\
\text { Ceramic } \\
\text { articulation) }\end{array}$ & $\begin{array}{l}\text { 46-year-old } \\
\text { male }\end{array}$ \\
\hline $\begin{array}{l}\text { Cooper et al. [5] } \\
2012\end{array}$ & $\begin{array}{l}10 \text { pts ( } 8 \text { female, } \\
2 \text { male) }\end{array}$ \\
\hline $\begin{array}{l}\text { Khair et al. [24] } \\
2013\end{array}$ & $\begin{array}{l}\text { Unknown } \\
\text { age, male, } \\
\text { modular fixed- } \\
\text { head unipolar } \\
\text { hemiarthroplasty }\end{array}$ \\
\hline $\begin{array}{l}\text { Mao et. al. [25] } \\
2012\end{array}$ & $\begin{array}{l}\text { 64-year-old } \\
\text { female }\end{array}$ \\
\hline $\begin{array}{l}\text { Clyburn [26] } \\
2013\end{array}$ & $\begin{array}{l}\text { 52-year-old } \\
\text { female }\end{array}$ \\
\hline $\begin{array}{l}\text { Scully et. al. } \\
\text { [27] } 2013\end{array}$ & $\begin{array}{l}80 \text {-year-old } \\
\text { male }\end{array}$ \\
\hline $\begin{array}{l}\text { Cook et. al. [13] } \\
2013\end{array}$ & $\begin{array}{l}\text { 2pts } \\
\text { (69-year-old } \\
\text { female, } 79 \text {-year- } \\
\text { old male) }\end{array}$ \\
\hline
\end{tabular}


ithic Femoral Components with Metal Femoral Head and Polyethylene Acetabular Liner

\begin{tabular}{|c|c|c|c|c|c|}
\hline $\begin{array}{l}\text { Time to pain after } \\
\text { index op (yr) }\end{array}$ & $\begin{array}{l}\text { Presenting } \\
\text { symptoms }\end{array}$ & Laboratory workup & $\begin{array}{l}\text { Pre-revision } \\
\text { imaging }\end{array}$ & Revision procedure & Notes \\
\hline 1.8 & $\begin{array}{l}\text { Enlarging mass } \\
\text { over gluteus } \\
\text { maximus }\end{array}$ & $\begin{array}{l}\text { ESR: elevated CRP: elevated; } \\
\text { Metal ions: not drawn; } \\
\text { Aspiration: negative culture }\end{array}$ & $\begin{array}{l}\text { MRI: well defined } \\
\text { soft tissue mass near } \\
\text { greater trochanter }\end{array}$ & $\begin{array}{l}\text { Head: ceramic } \\
\text { Acetabular shell: retained } \\
\text { Liner: ceramic } \\
\text { Femoral stem: retained }\end{array}$ & $\begin{array}{l}\text { Excessive fibrotic } \\
\text { soft tissue at time of } \\
\text { revision }\end{array}$ \\
\hline 1 & $\begin{array}{l}\text { Buttock and groin } \\
\text { pain }\end{array}$ & $\begin{array}{l}\text { ESR: normal CRP: elevated; } \\
\text { Cobalt: 0.5bbp (nml<0.007); } \\
\text { Chromium: } 0.09 \mathrm{ppb} \\
\text { (nml<0.006); Aspiration: } \\
\text { negative culture }\end{array}$ & $\begin{array}{l}\text { X-ray: unremarkable } \\
\text { CT: increased } \\
\text { volume of iliopsoas } \\
\text { MRA: cystic lesion } \\
\text { anteromedially in } \\
\text { iliopsoas }\end{array}$ & $\begin{array}{l}\text { Head: stainless steel } \\
\text { Acetabular shell: retained } \\
\text { Liner: polyethylene } \\
\text { Femoral stem: Stainless } \\
\text { steel }\end{array}$ & $\begin{array}{l}\text { Surface corrosion at } \\
\text { head-neck; disrupted } \\
\text { abductor insertion; } \\
\text { necrotic appearance of } \\
\text { tissue }\end{array}$ \\
\hline 2 & $\begin{array}{l}\text { Groin swelling; } \\
\text { painless medial } \\
\text { thigh mass }\end{array}$ & $\begin{array}{l}\text { Blood work: not described; } \\
\text { Metal ions: not described; } \\
\text { Aspiration: negative cultures }\end{array}$ & $\begin{array}{l}\text { CT: subcutaneous } \\
\text { fluid collection } \\
\text { extending from } \\
\text { iliopsoas to hip } \\
\text { joint; MRA: } \\
\text { communication } \\
\text { between hip joint and } \\
\text { medial thigh sinus }\end{array}$ & $\begin{array}{l}\text { Head: cobalt-chrome } \\
\text { alloy } \\
\text { Acetabular shell: revised, } \\
\text { not } \\
\text { specified } \\
\text { Liner: polyethylene } \\
\text { Femoral stem: revised, } \\
\text { not specified }\end{array}$ & $\begin{array}{l}\text { Foreign body } \\
\text { granuloma thigh mass; } \\
\text { black debris on morse } \\
\text { taper neck; metallic } \\
\text { fragments embedded in } \\
\text { ceramic }\end{array}$ \\
\hline $0.7-8.7$ & $\begin{array}{l}\text { 7-Pain (groin, } \\
\text { thigh, buttock, } \\
\text { trochanteric); 1- } \\
\text { weakness; 1- fluid } \\
\text { collection; 1- } \\
\text { swelling } \\
\end{array}$ & $\begin{array}{l}\text { ESR: mean } 47.3 \text { (range 4-108) } \\
\text { CRP: mean } 2.6 \text { (range 0.5-5.7) } \\
\text { Cobalt: mean } 9.55 \text { (range 1.6- } \\
\text { 42.45) Chromium: mean 1.39 } \\
\text { (range 0.18-3.28) Aspiration: } \\
\text { negative cultures }\end{array}$ & $\begin{array}{l}\text { Radiographs (10): all } \\
\text { interpreted as normal } \\
\text { MRI (3): large } \\
\text { fluid collection CT } \\
\text { (2): abnormal fluid } \\
\text { collection }\end{array}$ & $\begin{array}{l}\text { Ceramic head }+ \text { liner } \\
\text { exchange }(8) \text {; Ceramic } \\
\text { head, liner exchange, } \\
\text { acetabular revision }(2)\end{array}$ & $\begin{array}{l}\text { All patients with black } \\
\text { corrosion at trunnion; } \\
\text { abductor muscle } \\
\text { necrosis }(2)\end{array}$ \\
\hline 2 & Groin pain & $\begin{array}{l}\text { ESR: not reported CRP: not } \\
\text { reported; Cobalt: } 1.8 \mathrm{ppb}(\mathrm{nml} \\
<1 \mathrm{ppb}) \text {; Chromium: } 2.4 \mathrm{ppb} \\
\text { (nml < 1.4ppb); Aspiration: not } \\
\text { reported }\end{array}$ & $\begin{array}{l}\text { X-ray: osteolysis } \\
\text { surrounding } \\
\text { acetabulum }\end{array}$ & $\begin{array}{l}\text { Head: cobalt-chrome } \\
\text { alloy } \\
\text { Acetabular shell: cage } \\
\text { reconstruction } \\
\text { Liner: polyethylene } \\
\text { Femoral stem: } \\
\text { retained }\end{array}$ & $\begin{array}{l}\text { Surface corrosion at } \\
\text { trunnion; necrotic } \\
\text { appearance of tissue }\end{array}$ \\
\hline 4 & $\begin{array}{l}\text { Greater } \\
\text { trochanteric pain }\end{array}$ & $\begin{array}{l}\text { ESR: normal CRP: normal; } \\
\text { Cobalt: } 11.2 \mathrm{ng} / \mathrm{ml}(\mathrm{nml}<0.9) \text {; } \\
\text { Chromium: } 13 \mathrm{ng} / \mathrm{ml}(\mathrm{nml}< \\
\text { 0.3); Aspiration: negative culture }\end{array}$ & $\begin{array}{l}\text { X-ray: well-fixed } \\
\text { components without } \\
\text { signs of polyethylene } \\
\text { wear }\end{array}$ & $\begin{array}{l}\text { Head: ceramic } \\
\text { Acetabular shell: retained } \\
\text { Liner: ceramic } \\
\text { Femoral stem: retained }\end{array}$ & $\begin{array}{l}\text { Surface corrosion at } \\
\text { trunnion; metal debris } \\
\text { in tissue }\end{array}$ \\
\hline 5 & $\begin{array}{l}\text { Buttock and groin } \\
\text { pain; difficulty } \\
\text { ambulating }\end{array}$ & $\begin{array}{l}\text { ESR: elevated CRP elevated; } \\
\text { Aspiration: purulent, negative } \\
\text { culture }\end{array}$ & $\begin{array}{l}\text { X-ray: stable } \\
\text { implant with ischial } \\
\text { osteolysis }\end{array}$ & $\begin{array}{l}\text { First stage: Prostalac } \\
\text { Second stage: } \\
\text { Head: ceramic } \\
\text { Acetabular shell: revised, } \\
\text { not specified } \\
\text { Liner: polyethylene } \\
\text { Femoral stem: revised, } \\
\text { not specified }\end{array}$ & $\begin{array}{l}\text { Pseudotumor lateral } \\
\text { to greater trochanter; } \\
\text { damage to abductor } \\
\text { insertion; metallic } \\
\text { staining of tissue; black } \\
\text { debris at headneck } \\
\text { interface }\end{array}$ \\
\hline 5 & $\begin{array}{l}\text { Mass anterolateral } \\
\text { to greater } \\
\text { trochanter, pain, } \\
\text { difficulty } \\
\text { ambulating } \\
\end{array}$ & $\begin{array}{l}\text { ESR: normal CRP: normal; } \\
\text { WBC: normal }\end{array}$ & $\begin{array}{l}\text { MRI: well defined } \\
\text { cystic mass deep to } \\
\text { IT band expanding } \\
\text { out from hip joint }\end{array}$ & Head: ceramic & Scully et. al. [17] 2013 \\
\hline $1-4$ & $\begin{array}{l}\text { Groin and lateral } \\
\text { thigh pain }\end{array}$ & $\begin{array}{l}\text { ESR/CRP: not described; } \\
\text { Cobalt: mean } 6.6 \mathrm{ng} / \mathrm{ml} \text { (range } \\
6.3-6.9 \text { ); Chromium: mean } \\
\text { 1.56ng/ml (range } 0.47-2.65 \text { ); } \\
\text { Aspiration: negative culture }\end{array}$ & $\begin{array}{l}\text { US: large fluid } \\
\text { collection anterior to } \\
\text { greater trochanter in } \\
\text { continuity with hip } \\
\text { joint }\end{array}$ & $\begin{array}{l}\text { Finite material analysis } \\
\text { performed, revision not } \\
\text { specified }\end{array}$ & $\begin{array}{l}\text { Deep pseudotumor (x2) } \\
\text { adherent to capsule; } \\
\text { 3D metrology reveals } \\
\text { mechanical damage at } \\
\text { taper-trunnion overlap }\end{array}$ \\
\hline
\end{tabular}


While we nor Cooper et al. [5] could correlate femoral head diameter with trunnion corrosion in our small series, femoral head size and trunnion design features may be factors influencing the risk of corrosion [9-12]. Failure due to trunnion corrosion in MoP THA has been reported in two patients with large femoral heads ( $40 \mathrm{~mm}$ and 44 $\mathrm{mm}$ diameter) [13]. A significant elevation in serum cobalt levels in MoP THA has been reported when comparing a $36 \mathrm{~mm}$ femoral head to a $28 \mathrm{~mm}$ femoral head [14]. The Australian Registry 2011 annual report demonstrated increased revision rates at 10 years when head size in metalon-metal THAs was greater than $32 \mathrm{~mm}$ compared to those constructs in which the head size was equal to $32 \mathrm{~mm}$ or less [15]. This increase in failure was believed to be related to the larger head diameter increasing the load, torque, and micromotion at the trunnion interface. Trunnion design may be a factor as Jani et al. reported the lowest metal ion release, with a 12/14 trunnion taper with a proximal taper locking location as compared to a 10/12 taper with either distal or proximal locking location[16]. Furthermore, the amount of debris generated at the trunnion interface may be underappreciated; recent data shows that in metalon-metal THA, approximately one-third of the total volumetric wear is generated at the tapered head-stem junction, and it is unknown if such debris may be more biologically active than debris generated at the femoral head-acetabular liner interface [17]. With our small numbers we cannot comment on the length of the neck extension as a factor in failure in these patients. Based on correspondence with implant manufacturers, we did not identify any change in trunnion design or metal composition of the implants in the last decade.

Limitations of this study include a small cohort of patients, short duration of follow-up and lack of titanium metal ion levels in these patients. We do not know if the damage present on the trunnions of the retained femoral components will be problematic with longer follow-up. Titanium metal ion levels were not measured in our patients and could be factor in failure and a source of debris particularly as a recent ten-year study showed titanium levels peaked at 36 months in patients with similar constructs [20]. Furthermore we do not have a sense of the prevalence of corrosion causing failure in MoP THA in monolithic femoral components. A search of the FDA MAUDE database showed 18 reports of Accolade MoP THA stem failures and $15 \mathrm{M} / \mathrm{L}$ taper MoP THA stem failures due to metallosis, corrosion, pseudotumor, metallic debris, or elevated serum metal ion levels resulting in pain and/or loosening [18]. Interestingly, the Australian Registry 2012 annual report stated that metal sensitivity as a reason for revision increased from $1.2 \%$ to $5.9 \%$ over the past year, although the exact source of metal sensitivity was not specified [19].

Early failure in conventional MoP THA can occur due to corrosion at the head-neck interface. As radiographs and physical examination findings may be unremarkable, the diagnosis may be elusive early in the clinical course. In patients with unexplained pain after conventional THA, we will now frequently proceed with advance imaging and serum metal ion level testing. We recommend a heightened awareness of this mode of failure.

\section{Disclosure}

The authors declare that there is no conflict of interest regarding the publication of this paper. For full disclosures refer to last page of this journal.

\section{References}

1. Klapperich C, Graham J, Pruitt L, Ries MD. Failure of a metal-on-metal total hip arthroplasty from progressive osteolysis. J Arthroplasty. 1999 Oct:14(7):877-81.

2. Park YS, Moon YW, Lim SJ, Yang JM, Ahn G, Choi YL. Early osteolysis following second-generation metal-onmetal hip replacement. J Bone Joint Surg Am. 2005 Jul;87(7):1515-21

3. Willert HG, Buchhorn GH, Fayyazi A, Flury R, Windler M, Koster G, Lohmann CH. Metal-on-metal bearings and hypersensitivity in patients with artificial hip joints. A clinical and histomorphological study. J Bone Joint Surg Am. 2005 Jan; 87(1):28-36.

4. Fricka KB, Ho H, Peace WJ, Engh CA, Jr. Metal-on-metal local tissue reaction is associated with corrosion of the head taper junction. J Arthroplasty. 2012 Sep;27(8 Suppl):26-31 el

5. Cooper HJ, Della Valle CJ, Berger RA, Tetreault M, Paprosky WG, Sporer SM, Jacobs JJ. Corrosion at the headneck taper as a cause for adverse local tissue reactions after total hip arthroplasty. J Bone Joint Surg Am. 2012 Sep 19:94(18):1655-61.

6. Messer RL, Tackas G, Mickalonis J, Brown Y, Lewis JB, Wataha JC. Corrosion of machined titanium dental implants under inflammatory conditions. J Biomed Mater Res B. $2009 \mathrm{Feb} ; 88(2): 474-81$.

7. Souza ME, Lima L, Lima CR, Zavaglia CA, Freire CM. Effects of ph on the electrochemical behaviour of titanium alloys for implant applications. J Mater Sci Mater Med. 2009 Feb;20(2):549-52.

8. Tamam E, Turkyilmaz I. Effects of ph and elevated glucose levels on the electrochemical behaviour of dental implants. J Oral Implantol. 2012 Feb 29.

9. Brown SA, Flemming CA, Kawalec JS, Placko HE, Vassaux C, Merritt K, Payer JH, Kraay MJ. Fretting corrosion accelerates crevice corrosion of modular hip tapers. J Appl Biomater. 1995 Spring;6(1):19-26.

10. Evans EM, Freeman MA, Miller AJ, Vernon-Roberts B. Metal sensitivity as a cause of bone necrosis and loosening of the prosthesis in total joint replacement. J Bone Joint Surg Br. 1974 Nov;56-B(4):626-42.

11. Gilbert JL, Buckley CA, Jacobs JJ. In vivo corrosion of modular hip prosthesis components in mixed and similar metal combinations. The effect of crevice, stress, motion, and alloy coupling. J Biomed Mater Res. 1993 Dec;27(12):1533-44.

12. Jacobs JJ, Skipor AK, Patterson LM, Hallab NJ, Paprosky WG, Black J, Galante JO. Metal release in patients who have had a primary total hip arthroplasty. A prospective, controlled, longitudinal study. J Bone Joint Sur Am. 1998 Oct:80(10):1447-58.

13. Cook RB, Bolland BJ, Wharton JA, Tilley S, Latham JM, Wood RJ. Pseudotumour formation due to tribocorrosion at the taper interface of large diameter metal on polymer modular total hip replacements. J Arthroplasty. 2013 Sep;28(8):1430-6

14. Craig P, Bancroft G, Burton A, Collier S, Shaylor P, Sinha A. Raised levels of metal ions in the blood in patients who have undergone uncemented metal-on-polyethylene trident-accolade total hip replacement. Bone Joint J. $2014 \mathrm{Jan} ; 96-\mathrm{B}(1): 43-7$

15. Australian orthopaedic association (aoa). Australia 2011 joint registry annual report. 2011 [08/2013]; Available from: https://aoanjrr.dmac.adelaide.edu.au/en

16. Jani SC, Sauer WL, McLean TW, Lambert RD, Kovacs P. Fretting corrosion mechanisms at modular implant interfaces. In: Marlowe DE, Parr JE, Mayor MB, editors. Modularity of orthopedic implants, astm stp 1301: American Society for Testing and Materials; 1997

17. Matthies AK, Racasan R, Bills P, Blunt L, Cro S, Panagiotidou A, Blunn G, Skinner J, Hart AJ. Material loss at the taper junction of retrieved large head metal-on-metal total hip replacements. J Orthop Res. 2013 Nov:31(11):1677-85

18. U.S. Food and drug administration. Maude - manufacturer and user facility device experience database. 2013 [08/2013]; Available from: http://www.accessdata.fda.gov/scripts/cdrh/cfdocs/cfmaude/search.cfm.

19. Australian orthopaedic association (aoa). Australia 2012 joint registry annual report. 2012 [Accessed 08/2013] Available from: https://aoanjrr.dmac.adelaide.edu.au/en.

20. Levine BR, Hsu AR, Skipor AK, Hallab NJ, Paprosky WG, Galante JO, Jacobs JJ. Ten-year outcome of serum metal ion levels after primary total hip arthroplasty: A concise follow-up of a previous report*. J Bone Joint Surg Am. 2013 Mar 20;95(6):512-8.

21. Walsh AJ, Nikolaou VS, Antoniou J. Inflammatory pseudotumor complicating metal-on-highly cross-linked polyethylene total hip arthroplasty. J Arthroplasty. 2012 Feb;27(2):324 e5-8.

22. Lindgren JU, Brismar BH, Wikstrom AC. Adverse reaction to metal release from a modular metal-on-polyethylene hip prosthesis. J Bone Joint Surg Br. 2011 Oct;93(10):1427-30.

23. Bonnaig NS, Freiberg RA, Freiberg AA. Total hip arthroplasty with ceramic-on-ceramic bearing failure from third-body wear. Orthopedics. $2011 \mathrm{Feb} ; 34(2): 132$.

24. Khair MM, Nam D, DiCarlo E, Su E. Aseptic lymphocyte dominated vasculitis-associated lesion resulting from trunnion corrosion in a cobalt-chrome unipolar hemiarthroplasty. J Arthroplasty. $2013 \mathrm{Jan}$;28(1):196 e11-4 .

25. Mao X, Tay GH, Godbolt DB, Crawford RW. Pseudotumor in a well-fixed metal-on-polyethylene uncemented hip arthroplasty. The Journal of arthroplasty. 2012 Mar;27(3):493 e13-7.

26. Clyburn T. Pseudotumor in metal-on-polyethylene total hip arthroplasty. Reconstructive Rev. 2013;3(1):18-22

27. Scully WF, Teeny SM. Pseudotumor associated with metal-on-polyethylene total hip arthroplasty. Orthopedics. 2013 May;36(5):e666-70. 